\title{
Sensors and instruments for oceanic dissolved carbon measurements
}

\author{
U. Schuster ${ }^{1}$, A. Hannides ${ }^{2}$, L. Mintrop ${ }^{3}$, and A. Körtzinger ${ }^{4}$ \\ ${ }^{1}$ University of East Anglia, School of Environmental Sciences, Norwich, NR4 7TJ, UK \\ ${ }^{2}$ Department of Fisheries and Marine Research, Ministry of Agriculture, Natural Resources and the Environment, \\ Nicosia, Cyprus \\ ${ }^{3}$ MARIANDA, Marine Analytics and Data, Tulpenweg 28, Kiel, Germany \\ ${ }^{4}$ Leibniz Institute of Marine Sciences, Chemical Oceanography, Düsternbrooker Weg 20, Kiel, Germany
}

Received: 30 January 2009 - Published in Ocean Sci. Discuss.: 27 February 2009

Revised: 19 August 2009 - Accepted: 23 August 2009 - Published: 10 November 2009

\begin{abstract}
Highly accurate and precise measurements of marine carbon components are required in the study of the marine carbon cycle, particularly when investigating the causes for its variability from seasonal to interannual timescales. This is especially true in the investigation of the consequences of anthropogenic influences.

The analysis of any marine carbon component requires elaborate instrumentation, most of which is currently used onboard ships, either in manual or automated mode. Technological developments result in more and more instruments that have sufficient long-term reliability so that they can be deployed on commercial ships, surface moorings, and buoys, whilst the great technological and operational challenges mean that only few sensors have been developed that can be used for sub-surface in situ measurements on floats, robots, or gliders. There is a special need for autonomous instruments and sensors that are able to measure a combination of different components, in order to increase the spatial and temporal coverage of marine carbon data.
\end{abstract}

This paper describes analytical techniques used for the measurement of the marine dissolved carbon components, both inorganic and organic: the fugacity of $\mathrm{CO}_{2}$, total dissolved inorganic carbon, $\mathrm{pH}$, alkalinity, and dissolved organic carbon. By pointing out advantages, disadvantages, and/or challenges of the techniques employed in the analysis of each component, we aim to aid non-carbon marine scientists, sensor developers and technologists, in the decision of which challenges to address in further development.

Correspondence to: $\mathrm{U}$. Schuster

(u.schuster@uea.ac.uk)

\section{Introduction}

This paper is the outcome of the OceanSensors08 workshop, which was held at the Leibniz-Institut für Ostseeforschung, Warnemünde, Germany, from 31 March to 4 April 2008. The workshop was, and the resulting papers are, intended for "marine scientists, sensor developers and technologists with an interest in determining and shaping the future of ocean sensing" (http://www.io-warnemuende. de/conferences/oceans08/; accessed 26 August 2009). The workshop itself covered four broad areas: climate, ecosystems, hazards, and cross-cutting issues and emerging technologies. This paper covers instruments and sensors employed in measuring the components of the marine dissolved carbon cycle, none of which can be measured directly. The sections below describe the analytical principles, which are mainly used in instruments (defined here as analytical systems installed onboard ships, buoys, and moorings), and sensors (defined here as analytical systems which can be installed in situ on sub-surface floats or robots).

The oceanic carbon cycle is complex, being influenced by chemical, physical, as well as biological processes. Figure 1 shows a simplified schematic of the main processes involved $^{1}$.

Atmospheric $\mathrm{CO}_{2}$ is taken up by the oceans by transfer through the sea surface: the air-sea flux of $\mathrm{CO}_{2}$. Through the "physical carbon pump", this dissolved sea surface carbon can be transported in inorganic form out of the sun-lit surface layers by vertical mixing to intermediate or deep layers in the oceans, a process also depicted as intermediate and deep

\footnotetext{
${ }^{1}$ Components such as methane, carbon monoxide, and carbon isotopes are not included in this paper. Neither do we cover principles to measure marine particulate carbon.
}

Published by Copernicus Publications on behalf of the European Geosciences Union. 


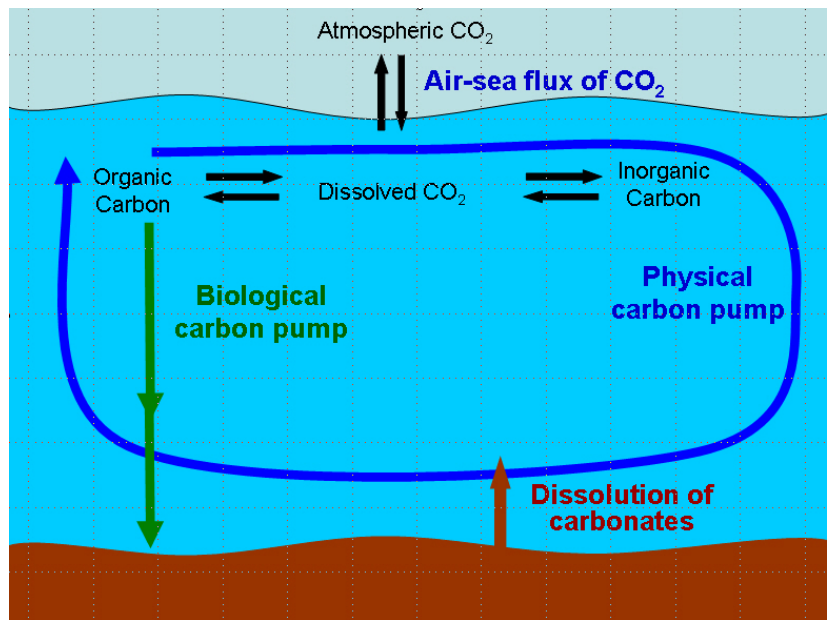

Fig. 1. Schematic of the oceanic carbon cycle, including air-sea flux, biological pump, physical pump and dissolution of carbonates.

water formation. Upwelling, also part of the physical carbon pump, can bring such carbon-rich deep water back into contact with the sea surface, reducing the uptake of atmospheric $\mathrm{CO}_{2}$ or even re-emitting $\mathrm{CO}_{2}$ to the atmosphere. The dissolved sea surface $\mathrm{CO}_{2}$ can also be converted to organic carbon by biological activity. As part of the "biological pump", this organic carbon is either re-cycled into the sea surface, or it sinks, to be mostly recycled at depth and, to a minor extent, to leave the ocean carbon cycle for $>1000$ years through burial in sediments. Many marine primary biological producers and consumers form tissue of calcium carbonate, i.e. particulate inorganic carbon, which can also undergo vertical export through the water column as well as burial in sediments.

Thus, oceanic carbon occurs in both inorganic and organic form, and as such as both dissolved and particulate carbon. The sections below, describing the technological principles employed to measure oceanic dissolved carbon, are therefore divided into dissolved inorganic carbon (Sect. 2) and dissolved organic carbon (Sect. 3). Note that particulate carbon is not covered in this paper. A specific scientific interest determines which parameters have to be measured. Table 1 summarizes scientific areas of interest when studying the oceanic dissolved carbon cycle, and the parameters most commonly measured in such studies.

Measurements of all of the oceanic dissolved carbon components are being done

- from surface waters to the greatest depths accessible;

- in discrete mode (using discrete seawater samples) as well as in continuous mode (in situ or in pumped surface waters);

- in natural waters as well as samples from experiments (such as mesocosm studies);
Table 1. Scientific areas of interest when studying the oceanic dissolved carbon cycle, and the parameters most commonly measured during such studies. Parameters listed are the fugacity of $\mathrm{CO}_{2}\left(f \mathrm{CO}_{2}\right)$, total dissolved inorganic carbon (DIC), total alkalinity (TA), $\mathrm{pH}$, and dissolved organic carbon (DOC). " $\mathrm{X}$ " depicts the main parameter(s) to be measured.

\begin{tabular}{lccccc}
\hline Scientific areas of interest & \multicolumn{5}{c}{ Parameters commonly measured } \\
\cline { 2 - 6 } & $f \mathrm{CO}_{2}$ & DIC & $\mathrm{TA}$ & $\mathrm{pH}$ & $\mathrm{DOC}$ \\
\hline Air-sea flux of $\mathrm{CO}_{2}$ & $\mathrm{X}$ & & & & \\
Ocean acidification & & $\mathrm{X}$ & $\mathrm{X}$ & $\mathrm{X}$ & \\
Carbon storage and transport & & $\mathrm{X}$ & $\mathrm{X}$ & & \\
in the oceans & & & & & \\
$\begin{array}{l}\text { Carbon "export", i.e. } \\
\text { the removal of carbon from } \\
\text { the surface waters to depth }\end{array}$ & & & & & $\mathrm{X}$ \\
\hline
\end{tabular}

- in (land-based) laboratories as well as field platforms, defined here as research ships or commercial vessels, and autonomous moorings, drifting buoys, floats, and other robotic platforms.

Challenges in developing instruments and sensors for oceanic carbon measurements, as common in the development of any instrument or sensor, include:

- accuracy/precision ${ }^{2}$

- routines for quality assessment (QA)/quality control of measurements (QC);

- long term drift

- size/weight;

- power requirements and power consumption;

- costs for installation and maintenance;

- sensitivity to biofouling/sedimentation;

- frequency of measurements;

- ruggedness;

- ease of use/maintenance;

- modularity;

- response time.

The first two challenges are naturally the same for all measurements, whilst others, e.g. size, weight, power requirements and power consumptions, are more dependent on the

\footnotetext{
${ }^{2} \mathrm{~A}$ glossary of terms and abbreviations used in this paper is given in Table 3 .
} 
platform to be used. Hence the order of these challenges is parameter as well as platform dependent.

In order to achieve the required accuracy and precision of measurements, easy access is often essential for calibration and maintenance. Therefore, a significant number of scientific marine carbon studies use instruments operated either manually or automatically onboard ships. The technologies are included in this paper. We also extend to sensors that can be used in situ, i.e. submerged below surface waters. Development, quality control, and calibration also requires suitable instruments in land laboratories; with or without modifications, most of these instruments can also be used onboard ships.

A report of the methodologies employed in oceanic carbon research in the late 1980s was published in 1992 (UNESCO, 1992). Since then, a huge number of instruments and sensors has been developed. Describing all in detail is far beyond the scope of this paper. Hence the emphasis here is on the technological principles employed, attempting to outline advantages and disadvantages, together with challenges for future developments. An internet-based catalogue of instruments and sensors currently used by the oceanographic carbon community is available through the International Ocean Carbon Coordination Project, UNESCO-IOC, Paris, France (IOCCP; http://ioc3.unesco.org/ioccp/Index.html; "Sensors"). This gives information and links for individual instruments and sensors. Most of the chemical methods are described in (Grasshoff et al., 1983). A handbook outlining the chemistry, thermodynamical and physical data, and standard operating procedures (SOPs) for the ship-board study of dissolved inorganic and organic carbon has recently been published (Dickson et al., 2007). Details of the marine carbonate chemistry are given in (Zeebe and Wolf-Gladrow, 2001).

\section{Oceanic carbon in dissolved inorganic form}

$\mathrm{CO}_{2}$ is taken up from the atmosphere by air-sea flux through the sea surface:

$$
\mathrm{CO}_{2} \text { (gaseous) } \leftrightarrow \mathrm{CO}_{2} \text { (aqueous) }
$$

Three equilibria then describe the aqueous reactions of inorganic carbon chemistry in seawater:

$\mathrm{CO}_{2}+\mathrm{H}_{2} \mathrm{O} \leftrightarrow \mathrm{H}_{2} \mathrm{CO}_{3}$

* Strictly speaking $\mathrm{CO}_{2}$ as shown there refers to a hypothetical species (often referred to as $\mathrm{CO}_{2} *(\mathrm{aq})$ ) which is defined as the sum of the concentrations of $\mathrm{CO}_{2}(\mathrm{aq})$ and $\mathrm{H}_{2} \mathrm{CO}_{3}(\mathrm{aq})$.

$$
\begin{aligned}
& \mathrm{H}_{2} \mathrm{CO}_{3} \leftrightarrow \mathrm{H}^{+}+\mathrm{HCO}_{3}^{-} \\
& \mathrm{HCO}_{3}^{-} \leftrightarrow \mathrm{H}^{+}+\mathrm{CO}_{3}^{2-}
\end{aligned}
$$

None of the concentrations of the components involved in the dissolved inorganic carbon chemistry can be measured directly in seawater. The inorganic dissolved carbon system is described by temperature, salinity, pressure, and the following four measurable parameters:

1. fugacity of $\mathrm{CO}_{2}\left(f \mathrm{CO}_{2}\right)$,

2. dissolved inorganic carbon (DIC, i.e. the sum of the concentrations of dissolved $\mathrm{CO}_{2}$, bicarbonate and carbonate; also depicted as $C_{T}$ or $\Sigma \mathrm{CO}_{2}$ ),

3. $\mathrm{pH}$, and

4. total alkalinity (TA; also depicted as TAlk or $A_{T}$ )

If at least two of these four parameters are measured in a sample, the other two can be calculated using equilibrium constants, temperature, pressure, and salinity (Lewis and Wallace, 1998; Dickson et al., 2007). The particular research question which has to be answered determines which of the four parameters are measured, in order to obtain the highest accuracy.

In the following 4 sections, the analytical principles for the dissolved inorganic carbon parameters are described separately. However, a great need in the marine community are instruments or sensors that are able to measure a combination of these parameters to the required accuracy and precision, in addition to at least seawater temperature and salinity.

\subsection{The fugacity of $\mathrm{CO}_{2}\left(f \mathrm{CO}_{2}\right)$}

The partial pressure of $\mathrm{CO}_{2}\left(p \mathrm{CO}_{2}\right)$ is equivalent to the mole fraction of $\mathrm{CO}_{2}\left(x \mathrm{CO}_{2}\right)$ in air that is in equilibrium with seawater, multiplied with the total pressure $(p)$ of equilibration:

$p \mathrm{CO}_{2}=x \mathrm{CO}_{2} * p$

The fugacity of $\mathrm{CO}_{2}$ in seawater $\left(f \mathrm{CO}_{2}\right)$ is defined as the partial pressure of $\mathrm{CO}_{2}$ in air that is in equilibrium with seawater, taking into account that $\mathrm{CO}_{2}$ is not an ideal gas, i.e. considering molecular interactions of $\mathrm{CO}_{2}$ (e.g. with $\mathrm{H}_{2} \mathrm{O}$ and other $\mathrm{CO}_{2}$ molecules). The non-ideal character of $\mathrm{CO}_{2}$ at atmospheric pressure is rather small in the concentration range of interest here, so the $p \mathrm{CO}_{2}$ is frequently used. For very precise calculation the non-ideal behaviour has to be taken into account, however, and $f \mathrm{CO}_{2}$ should be used. In this present work, we use the term $f \mathrm{CO}_{2}$ throughout.

The calculation of $f \mathrm{CO} 2$ is given in Dickson et al. (2007), SOP number 24, and is reported in units of pressure. For historical reasons this is usually microatmospheres [ $\mu \mathrm{atm}]$ rather than Pascal $[\mathrm{Pa}]$. Surface seawater $f \mathrm{CO}_{2}$ typically ranges from 250 to $550 \mu \mathrm{atm}$, yet can reach $2000 \mu \mathrm{atm}$ at depth (at $20^{\circ} \mathrm{C}$ ). In order to reliably detect anthropogenic influences on the air-sea exchange of $\mathrm{CO}_{2}$, sea surface $f \mathrm{CO}_{2}$ should be determined to an accuracy of $1 \mu \mathrm{atm}$.

Seawater $f \mathrm{CO}_{2}$ cannot be measured directly in the water phase. Hence, the first step of measurement is to equilibrate seawater with a medium, in which $\mathrm{CO}_{2}$ can be measured. Seawater $f \mathrm{CO}_{2}$ is therefore determined by 
Table 2. Different techniques employed to determine oceanic $f \mathrm{CO}_{2}$, with the different techniques of equilibration used, together with detection of $\mathrm{CO}_{2}$ through to the platforms on which they are used.

\begin{tabular}{lllll}
\hline Mode of equilibration & discrete & continuous & continuous & continuous \\
\hline $\begin{array}{l}\text { Equilibration of } \mathrm{CO}_{2} \\
\text { in seawater with } \mathrm{CO}_{2} \text { in }\end{array}$ & air & air & air & $\begin{array}{l}\text { a pH-sensitive } \\
\text { indicator solution }\end{array}$ \\
Equilibration achieved & in a sample flask & in an equilibrator & through a membrane & through a membrane \\
Detection of $\mathrm{CO}_{2}$ by & GC, IR & GC, IR & Spectrophotometry & Spectrophotometry \\
Platforms used: & $\begin{array}{l}\text { commercial ships, } \\
\text { research ships }\end{array}$ & $\begin{array}{l}\text { commercial ships, } \\
\text { research ships }\end{array}$ & $\begin{array}{l}\text { Moorings, gliders, } \\
\text { buoys }\end{array}$ & $\begin{array}{l}\text { Moorings, gliders, } \\
\text { buoys }\end{array}$ \\
\hline
\end{tabular}

1. the measurement of the mole fraction of $\mathrm{CO}_{2}\left(x \mathrm{CO}_{2}\right)$ in air that has been equilibrated with seawater, or

2. the measurement of the $\mathrm{pH}$ of an indicator dye solution, after the solution has been equilibrated with seawater (the $\mathrm{pH}$ is determined by the equilibrated $\mathrm{CO}_{2}$ it contains).

Table 2 outlines the different techniques of equilibration used, together with analyses of $\mathrm{CO}_{2}$ through to the platforms on which they are used.

The exact technique of equilibration chosen depends on the scientific question under investigation, the platform used for measurements, and the geographical location. Equilibration between seawater and air is mainly used for continuous surface measurements, on board either research or commercial vessels, and for analysing discrete samples, taken during mesocosm experiments or at depth onboard research ships. In geographical locations where continuous shipboard measurements are rare or impossible, e.g. in the Southern Ocean or at depth using floats, equilibration is typically done through membrane-based approaches.

\subsubsection{Determination of $f \mathrm{CO}_{2}$ by measurement of $x \mathrm{CO}_{2}$ in air}

$\mathrm{CO}_{2}$ is firstly equilibrated between seawater and air (described in (b) below), followed by the measurement of $x \mathrm{CO}_{2}$ in the air. $x \mathrm{CO}_{2}$ in air can be measured by gas chromatography (GC) or by non-dispersive infrared spectrometry (NDIR).

(a) Analytical principle for $x \mathrm{CO}_{2}$ in air:

(a-1) The analytical technique of $x \mathrm{CO}_{2}$ in equilibrated air by $\mathrm{GC}$ is based on the catalytic conversion of the $\mathrm{CO}_{2}$ to $\mathrm{CH}_{4}$, followed by flame ionization detection (FID) of the $\mathrm{CH}_{4}$ (Weiss, 1981; Weiss et al., 1992; Robertson et al., 1993; Dickson et al., 2007). Underway analytical systems with GCs for the measurement of $x \mathrm{CO}_{2}$ were developed in the 1970s and extensively used until the 1990s, when the analysis by NDIR absorption spectrometry began to be used more widely.
The advantages of using a gas chromatograph include the need for only small air samples, the non-interference of moisture in the air sample, and the linear response of the FID over a large range of $x \mathrm{CO}_{2}$ concentrations. The latter is particularly advantageous for discrete measurements due to the large concentration range encountered throughout the water column.

(a-2) The analytical technique of $x \mathrm{CO}_{2}$ in equilibrated air by NDIR absorption spectrometry is based on the absorption of infrared radiation by $\mathrm{CO}_{2}$ molecules.

Advantages are that NDIR analysers can easily be included in automated instruments, making them suitable for systems on buoys and moorings. With care (e.g. temperature control) and automatic zero-ing of the $\mathrm{CO}_{2}$ channel in the analyser, long term drift can be kept to a minimum. Disadvantages are that moisture absorbs infra-red radiation and that the equilibrated air is at $100 \%$ humidity at the temperature of equilibration; this requires that either the air to be analysed dried prior to the measurement, or $x \mathrm{H}_{2} \mathrm{O}$ has to be measured parallel to the $x \mathrm{CO}_{2}$, followed by mathematical moisture correction. Additionally, NDIR analyser can be affected by vibration, e.g. on ships, causing increased instability of the readings. For highly accurate measurements, temperature control of the optical cell in the NDIR is also required (Pierrot et al., 2009; Murphy et al., 1998).

(b) Equilibration of $\mathrm{CO}_{2}$ between air and seawater can be achieved either by direct contact between air and seawater (discrete or continuous), or by permeation of $\mathrm{CO}_{2}$ through a membrane (continuous).

(b-1) Equilibration in discrete seawater samples is achieved either by pumping, using a closed loop, a known volume of air through a known volume of seawater in a flask, or by introducing a known small volume of air into a sealed sample bottle filled with seawater. Once equilibrium of $\mathrm{CO}_{2}$ between the two phases is achieved, $x \mathrm{CO}_{2}$ in the equilibrated air can then be measured by either GC or NDIR, described above. The air used for equilibration needs to contain a known initial amount of $\mathrm{CO}_{2}$, ideally close to the $f \mathrm{CO}_{2}$ of the seawater sample, in order to minimise the perturbation in the sample's $\mathrm{CO}_{2}$ concentration. During the equilibration 
process, a constant known temperature and pressure within the closed circuit needs to be maintained.

These measurements are carried out during mesocosm experiments, or onboard research vessels to predominately determine $f \mathrm{CO}_{2}$ in samples collected at depth. A standard operating procedure for these measurements, applying gas chromatography for analysis, is described by Dickson et al. (2007), SOP number 04.

A disadvantage of such instrumentation is that it is elaborate, since it requires the control and measurement of temperature of the seawater sample to $\pm 0.05^{\circ} \mathrm{C}$, pressure measurement to \pm 0.5 mbar, several standard (and head space) gases, and $\mathrm{CO}_{2}$-free carrier gas (for $\mathrm{GC}$ analysis). It also requires a major correction to in situ temperature, since the measurements are usually performed at a standard temperature (e.g. $20^{\circ} \mathrm{C}$ ). Yet with care, precision of below $0.25 \%$ of $f \mathrm{CO}_{2}$ can be achieved. Typically, discrete $f \mathrm{CO}_{2}$ measurements are combined with measurements of at least one other $\mathrm{CO}_{2}$ system parameter (e.g. DIC or TA).

(b-2) Continuous mode equilibration is achieved by pumping a fixed volume of air around a circuit that contains an "equilibrator", where the $\mathrm{CO}_{2}$ equilibrates between a continuous flow of seawater and a counter-flow of air. The flow of seawater needs to be sufficiently large that it can be considered infinite. The volume of air, in contrast, should be minimised, ensuring that the $\mathrm{CO}_{2}$ in the air adjusts to the equilibrium value with the seawater, without changing the $\mathrm{CO}_{2}$ in the seawater noticeably. Once equilibrium of $\mathrm{CO}_{2}$ between the two phases is achieved, the mole fraction of $\mathrm{CO}_{2}\left(x \mathrm{CO}_{2}\right)$ in the equilibrated air can then be measured by either GC or NDIR, described above. Throughout, temperature and pressure within the equilibrator need to be measured to within $\pm 0.01^{\circ} \mathrm{C}$ and $\pm 0.5 \mathrm{mbar}$, respectively, to achieve $f \mathrm{CO}_{2}$ to within $2 \mu \mathrm{atm}$ (http://ioc3.unesco.org/ioccp/Docs/ TsukubaWSdocs/NOAApCO2workshop_report.doc, and ideally to within $\pm 0.01^{\circ} \mathrm{C}$ and $\pm 0.2 \mathrm{mbar}$, respectively. Additionally, in situ seawater temperature needs to be measured, so that the effect of the temperature change from seawater inlet to equilibrator can be corrected for (ideally $< \pm 0.5^{\circ} \mathrm{C}$ change). A good recommendation is to measure in situ salinity as well.

A number of different types of equilibrators have been developed, all of which attempt to optimise the surface area between seawater and air. They include the shower-head type (Robertson et al., 1993; Weiss et al., 1992; Feely et al., 1998), the percolator type (Cooper et al., 1998; Schuster and Watson, 2007), the bubble type, the laminar flow type, and a combination of these types in one equilibrator (Lüger et al., 2004; Nojiri et al., 1999; Körtzinger et al., 1996). Measurements using an equilibrator are predominately carried out onboard ships, both on research and on commercial vessels, yet can be adapted to be installed on moorings.

The advantage of equilibrator based systems is that with care, highly accurate and precise data can be obtained. Disadvantages of equilibrators are their size, possible biofouling progressively blocking the seawater inlet to the equilibrator. Additionally, equilibrators need to be vented to maintain ambient pressure inside them, which can lead to contamination of the air inside the equilibrator. Also onboard ships, the position of the seawater inlet needs to be chosen carefully, in order to minimise artefacts caused by the ship's movement and hull-structure. A very detailed standard operating procedure of one such ship-board system for the underway, continuous determination of $f \mathrm{CO}_{2}$ in surface seawater is given by Dickson et al. (2007), SOP number 05.

(b-3) Continuous mode equilibration through a membrane is achieved by separating the gas phase from the seawater by e.g. a silicon or teflon membrane, and analysing the $x \mathrm{CO}_{2}$ in air by NDIR. In these systems, the hydrostatic pressure of the ambient seawater requires to be resisted by special measures (i.e. rigid membrane support in planar or tubular form).

The advantage of these instruments include that they can be installed on sub-surface platforms such as floats, and their potentially small size. Disadvantages include biofouling of the membrane and drift over time.

\subsubsection{Determination of $f \mathrm{CO}_{2}$ by the $\mathrm{pH}$ of an indicator dye solution}

This analytical technique of $\mathrm{CO}_{2}$ in seawater is based on the $\mathrm{pH}$ change of a $\mathrm{pH}$-sensitive colour indicator dye solution, in which the $\mathrm{CO}_{2}$ is equilibrated across a membrane with seawater. The $\mathrm{pH}$ of the equilibrated indicator dye then depends on the $\mathrm{CO}_{2}$ content.

In such instruments (e.g. Lefevre et al., 1993; deGrandpre et al., 2000), the equilibrated dye is transferred to an optical cell, where the absorbance is measured spectrophotometrically at wavelengths of the absorbance maxima of the indicator dye's acid and base forms, and at a non-absorbing wavelength (baseline). The indicator dye solution is prepared by diluting a concentrated solution of the $\mathrm{pH}$ indicator with synthetic seawater. The colour indicator solution has to have an ionic strength close to that of seawater (by salinity and bicarbonate content), to minimise the osmotic pressure across the membrane. The alkalinity of the dye solution is adjusted in order to optimise the $\mathrm{pH}$ change across the expected $f \mathrm{CO}_{2}$ range. A mercuric chloride solution is usually added to the colour indicator solution, to prevent biofouling of the membrane.

The $f \mathrm{CO}_{2}$ values can be calculated from the spectrophotometric absorbance and temperature data, together with the dissociation constant of the dye, dissociation constants of carbonic acid in seawater, the solubility coefficient, and the alkalinity and concentration of the dye. This technique has been developed primarily for buoys and moorings, in order to obtain oceanic measurements at remote locations, such as the Southern Ocean. Alternatively, the absorbance of the specific dye solution can be calibrated in the laboratory across the expected ranges in $f \mathrm{CO}_{2}$ and temperature, so that 
measurements in the field can be directly related to $f \mathrm{CO}_{2}$, albeit at lower accuracy.

A challenge for any instrument deployed on buoys or moorings is to minimise long-term drift. Since the dye solutions fade over time, an longer-term stability can be achieved by adding the measurement of the absorbance at the wavelength of the isosbestic point of the indicator dye's acid and base forms. Additionally, a $\mathrm{pH}$ based technique requires sufficiently high sensitivity to resolve $f \mathrm{CO}_{2}$ changes in seawater.

\subsection{3 $\mathrm{fCO}_{2}$ instrument/sensor intercomparisons}

A number of intercomparison experiments of $f \mathrm{CO}_{2}$ instruments have been carried out. In 1994, a laboratory intercomparison was carried out at Scripps Institution of Oceanography. In 1996, a ship-board intercomparison was carried out onboard FS Meteor during a crossAtlantic cruise (Körtzinger et al., 1998). This identified that the temperature in the equilibrator was not always measured to the accuracy required for high-quality $f \mathrm{CO}_{2}$ data. In 2003, a pool-side intercomparison experiment was carried out in Japan (http://ioc3.unesco.org/ioccp/ Docs/TsukubaWSdocs/WG1SummaryRpt.pdf). This identified that the performance of equilibrators can introduce differences in measured $f \mathrm{CO}_{2}$. For 2009, two intercomparisons are planned: one again as a pool-side intercomparison in Japan, continuing the 2003 experiment, and an open-ocean one by the Alliance for Coastal Technologies (http://www.act-us.info/tech_evaluations.php).

\subsection{Dissolved inorganic carbon (DIC)}

DIC in seawater is defined as the sum of the concentrations of dissolved $\mathrm{CO}_{2}$, carbonic acid, bicarbonate, and carbonate:

$$
\mathrm{DIC}=\left[\mathrm{CO}_{2}(\mathrm{aq})\right]+\left[\mathrm{H}_{2} \mathrm{CO}_{3}\right]+\left[\mathrm{HCO}_{3}^{-}\right]+\left[\mathrm{CO}_{3}^{2-}\right]
$$

It is reported as micromoles carbon per kilogram of seawater $\left[\mu \mathrm{mol} \mathrm{kg}^{-1}\right]$. Seawater DIC concentrations typically range from 1800 to $2300 \mu \mathrm{mol} \mathrm{kg}^{-1}$, yet can reach $4300 \mu \mathrm{mol} \mathrm{kg}^{-1}$ in extreme environments (e.g. the Black Sea). For anthropogenic investigations, it needs to be determined to an accuracy of $1 \mu \mathrm{mol} \mathrm{kg}^{-1}$. Certified calibration standards for DIC measurements are available since 1991 from Scripps Institution of Oceanography (http://andrew. ucsd.edu/co2qc/index.html), enabling a globally consistent standardization of quality control of measurements.

DIC is measured by

1. coulometry, after acidifying a known amount of seawater with phosphoric acid, stripping the released $\mathrm{CO}_{2}$ by an inert, $\mathrm{CO}_{2}$-free carrier gas, and measuring the amount of $\mathrm{CO}_{2}$ in this gas by coulometry, or

2. NDIR, after acidifying a known amount of seawater with phosphoric acid, stripping the released $\mathrm{CO}_{2}$ by an inert, $\mathrm{CO}_{2}$-free carrier gas, and measuring the amount of $\mathrm{CO}_{2}$ in this gas by absorption spectrometry, or

3. potentiometry, during which a seawater sample of known mass is titrated with a strong acid in a closed cell.

\subsubsection{Determination of DIC by coulometry}

The $\mathrm{CO}_{2}$ released from a seawater sample by acidification is passed into a solution containing a $\mathrm{pH}$-sensitive colour indicator, where $\mathrm{CO}_{2}$ reacts to form a strong acid, which can then be titrated coulometrically by electrochemical generation of a strong base. Due to the necessity to carefully control the performance of a coulometer, coulometer-based systems can only be used for discrete samples on board research vessels. Such a system using coulometers is described by Dickson et al. (2007), SOP02.

Disadvantages are that such measurements are elaborate. They require careful dispensation of a precisely known volume of seawater into the chamber where the sample is acidified, high-quality measurement of temperatures, careful monitoring of coulometer background levels, and regular calibration. Additionally, hazardous chemicals are used in the analysis; since these chemicals need to be replaced at least at daily intervals, coulometers are affected by down-times of hours for the chemical conditioning of the coulometer solution. For improved quality of measurements, the coulometer cell should be temperature controlled.

The advantage is that with care, the highest precision and accuracy can be achieved.

\subsubsection{Determination of DIC by non-dispersive infrared absorption}

The $\mathrm{CO}_{2}$ released from a seawater sample by the acidification is passed through a NDIR (e.g. Friederich et al., 2002), such as described in Sect. 2.1.1 for the determination of $f \mathrm{CO}_{2}$. To achieve the required accuracy and precision, the analyser needs to be carefully temperature controlled in such systems.

\subsubsection{Determination of DIC by potentiometry}

A seawater sample of known mass is titrated with a strong acid (e.g. $0.1 \mathrm{M} \mathrm{HCl}$ ) in a closed cell. The addition of the acid changes the electromotive force (e.m.f.) of the seawater, which can be followed by a pH sensitive electrode (combination electrode or electrode pair). During titration, the titration cell needs to be kept at constant temperature. Since $\mathrm{CO}_{2}$ gas is produced near the location of acid addition in the seawater solution, this gas must be kept from escaping the system so that it re-dissolves; hence a closed titration cell is used.

This technique can be used if a combined analysis of DIC and total alkalinity is required (Dickson et al., 2007, SOP 
number 03a). However, a higher accuracy of DIC measurements can be achieved if DIC measurement by coulometry is done, as described in Sect. 2.2.1 above.

\section{$2.3 \mathrm{pH}$}

$\mathrm{pH}$ is a measure of the acidity or basicity of a solution. It is defined as the negative of base 10 logarithm of the hydrogen ion concentration of a solution. $\mathrm{pH}$ has been expressed on a number of different scales, i.e. the total scale, the National Bureau of Standards (NBS) scale, the seawater scale, and the free scale.

On the total scale, it is defined as:

$$
\begin{aligned}
\mathrm{pH}= & {\left[\mathrm{H}^{+}\right]_{\text {free }}+\left[1+S_{T} / K_{S}\right] \approx\left[\mathrm{H}^{+}\right]_{\text {free }}+\left[\mathrm{HSO}_{4}^{-}\right] } \\
& (\text {for } \mathrm{pH}>4)
\end{aligned}
$$

where $S_{T}$ is the total sulfate concentration, and $K_{S}$ is the acid dissociation constant for $\mathrm{HSO}_{4}^{-}$.

A full discussion on the other scales in beyond this paper, and we refer the interested reader to e.g. (Dickson, 1984, 1993) for a detailed discussion of the various $\mathrm{pH}$ scales that have been used in seawater.

Oceanic $\mathrm{pH}$ ranges from 7.8 to 8.3 , but can reach more extreme values in e.g. anoxic basins such as the Black Sea or in hydrothermal fluids (e.g. Charlou et al., 2000). For oceanic carbon research purposes, it should be determined to an accuracy of $\pm 0.002 \mathrm{pH}$ units.

Certified calibration standards for $\mathrm{pH}$ systems are not yet available, yet a limited number of prototype reference material is available (http://andrew.ucsd.edu/co2qc/index.html).

$\mathrm{pH}$ of seawater can be measured by

\section{1. potentiometry or}

\section{2. spectrophotometry.}

\subsubsection{Determination of $\mathrm{pH}$ by potentiometry}

In the field of electroanalytical chemistry, potentiometry is the measurement of the electrical potential difference that develops between the ion activity in two different solutions separated by an interface. The potential is the result of the free energy change that would occur if the chemical phenomena were to proceed until equilibrium. If the activity of ions on one side of the interface is held constant, the electrical potential is related to the activity of ions on the other side.

A combined $\mathrm{pH}$ glass electrode, for example, has a thin membrane of hydrogen-sensitive glass, formed into a bulb and melted to a glass shaft. The inside is filled with a liquid of known, constant composition, which creates a potential difference across the glass membrane against the liquid of interest on its outside. The difference in electrical potential is measured by an electrode inside the glass bulb, and a reference electrode outside. The reference electrode can be separated from the glass electrode, or as in the combined $\mathrm{pH}$ glass electrode, the reference electrode is placed inside a mantle surrounding the glass electrode, but its liquid connected to the outside through a glass frit. The measured potential represents the sum of several individual potentials along the entire setup. Since only the potential across the glass membrane is of interest, all others (e.g., junction potential, asymmetry potential) as well as their change with time need to be accounted for by frequent calibration.

The response of any pair of glass electrode/reference electrode is calibrated using buffers prepared in the laboratory. Besides having a known $\mathrm{pH}$, buffer solutions are required to be very stable over time. A large number of different buffers have been developed for $\mathrm{pH}$ in seawater measurements, and need to be chosen according to the measurements to be made.

A combined glass electrode and reference electrode can be used, yet often better measurements are achieved with separate glass electrode and reference electrode. The glass electrode/reference electrode pair measures the e.m.f. in a standard buffer to obtain background value, and then in a seawater sample, whilst both liquids are at the same temperature. The e.m.f. of the electrode pair can be measured with a voltmeter of high input impedance. The seawater $\mathrm{pH}$ can then be calculated using the e.m.f. of the buffer and seawater sample, temperature, and salinity. The standard operating procedure of such a measurements is given by Dickson et al. (2007), SOP06a.

Challenges of such instrumentation are careful temperature control of solutions used, electrode drift, extremely careful preparation of the buffer solutions, problems with reference electrodes, and the need for frequent calibrations. SCOR Working Group 75 reported that by 1988, the precision of $\mathrm{pH}$ measurements was $\pm 0.02 \mathrm{pH}$ units, yet with care precisions of $0.002 \mathrm{pH}$ units can be achieved (Byrne and Breland, 1989).

\subsubsection{Determination of $\mathrm{pH}$ by spectrophotometry}

Spectrophotometry has been used increasingly especially since the late 1980s. First the multi-wavelength absorbance is measured in a seawater sample, then again after a $\mathrm{pH}$ sensitive indicator dye is added to the seawater sample. It is based on the principle that the corresponding acid and base forms of a $\mathrm{pH}$ indicator dye have different colours, hence different absorption bands. The total hydrogen concentration is then calculated from the absorbances measured, temperature, salinity, and the dissociation constant of the indicator dye used.

A number of different indicator dyes are used for $\mathrm{pH}$ determination, and research is continuing for optimal combinations of e.g. indicator dye and multi-wavelength chosen. The standard operating principle for ship-board measurements of discrete samples using $m$-cresol purple as indicator is given by Dickson et al. (2007), yet developments are being made to develop an automated system for the deployment on ships, buoys and moorings (DelValls, 1999; Bellerby et al., 2002). 
Challenges of these systems are careful temperature control of solutions and spectrophotometer cell, preparing indicator solution with ionic strength close to that of seawater, homogenous mixing of sample and dye solution.

Potential accuracy is $\pm 0.002 \mathrm{pH}$, sensitivity and long-term reproducibility can be better than $\pm 0.001 \mathrm{pH}$ (e.g. Friis et al., 2004).

\subsection{Total Alkalinity (TA)}

The total alkalinity of seawater is defined as the "number of moles of hydrogen ion equivalent to the excess of proton acceptors (bases formed from weak acids with a dissociation constant $\mathrm{K} \leq 10^{-4.5}$ at $25^{\circ} \mathrm{C}$ and zero ionic strength) over proton donors (acids with $K>10^{-4.5}$ ) in 1 kilogram of sample" (Dickson, 1981). Total alkalinity encloses contributions from the alkalinity of all relevant ions in the sample. For seawater with conservative composition, the contribution from total borate can be derived from salinity; other concentrations, such as phosphate and silicate, which normally constitute very small contributions to the total alkalinity, are often available from parallel nutrient measurements. Concentrations of ammonia and sulfide are typically so low in the open ocean that their contributions to total alkalinity can (in most cases) be neglected. In coastal waters and anoxic waters, the situation can be different; these contributions, though minor, need to be estimated or measured separately.

A recent definition of alkalinity (Wolf-Gladrow et al., 2007), which is entirely consistent with the one of (Dickson, 1981), takes a different approach that helps to infer the effects of biogeochemical processes on alkalinity.

TA is reported as micromoles per kilogram of seawater $\left[\mu \mathrm{mol} \mathrm{kg}^{-1}\right]$ or as microequivalent per kilogram $\left[\mu \mathrm{Equ} \mathrm{kg}^{-1}\right]$. Please note that in some literature, alkalinity is reported as $\left[\mu \mathrm{moll}^{-1}\right]$ or $\left[\mu \mathrm{Eq}^{-1}\right]$, which is not independent of seawater density, i.e. temperature and salinity.

Oceanic values are usually between 2000 and $2500 \mu \mathrm{mol} \mathrm{kg}^{-1}$, yet can reach $4600 \mu \mathrm{mol} \mathrm{kg}^{-1}$ (e.g. Black Sea). Total alkalinity needs to be measured to within $\pm 1 \mu \mathrm{mol} \mathrm{kg}^{-1}$ in ocean carbon studies to detect anthropogenic influences. For calculations in the sea water $\mathrm{CO}_{2}$ system, the carbonate alkalinity is important. This is therefore calculated by subtracting all other alkalinity contributions from the measured total (or titration) alkalinity.

In principle, alkalinity is determined by adding acid to a seawater sample and analyzing the change in the e.m.f. of a $\mathrm{pH}$ electrode caused hereby. The number of steps can range from one to a full titration (20 or more acid increments added). As for $\mathrm{pH}$, the $\mathrm{pH}$ change caused by the acid addition can be measured by

1. potentiometric titration or

2. spectrophotometrically.

The most common method today, however, is potentiometric titration in a closed or open cell.

\section{Determination of TA by potentiometric titration}

Potentiometric titration in a closed cell follows the same procedure as outlined for the determination of DIC by potentiometry (Sect. 2.3.3) and is needed only if a DIC value is to be derived from the titration. It should be noted that this determination of DIC is of lower accuracy than the coulometric technique described in Sect. 2.2.1.

So, if other methods are used for DIC measurements, the alkalinity titration cell can be open, since $\mathrm{CO}_{2}$ exchange only affects the DIC value, but not alkalinity. The seawater sample is titrated with hydrochloric acid, which has an ionic strength similar to that of seawater. Titration is monitored by reading the e.m.f. of a glass electrode/reference electrode pair. The detection of the titration end point from the titration results is difficult and requires mathematical procedures. This can be the linearization of the titration curve by a GRAN plot, or the comparison of the experimental titration curve to a theoretical calculated titration curve and mathematical minimization of the difference by adjusting the parameters of the theoretical curve fit.

Although, in principle, alkalinity could be determined from the $\mathrm{pH}$ change by a single acid addition, precision greatly increases if more titration points can be used for the calculation. Temperature needs to be kept constant during titration and good mixing is required. However, the stabilization of the potential in the solution is a rather slow process (faster at higher temperature), so a full titration does take some time (typically 10-20 min).

Spectrophotometric titrations of alkalinity have been described, but are not (yet) widely used. The need for one or (better) more titration step(s) in all methods proposed so far, makes it difficult to develop a sensor based on this analytical approach.

\section{Dissolved oceanic carbon}

Dissolved organic carbon (DOC) is defined as the fraction of organic carbon that passes through a filter (typically of 0.2 $0.45 \mu \mathrm{m}$ pore size) and survives acidification and sparging (Dickson et al., 2007). The determination of DOC concentrations has been the topic of considerable attention and activity (e.g., see discussions in Pilson, 1998; Hansell and Carlson, 2001).

There are two noteworthy facts about DOC and its measurement:

(a) The introduction in 1988 of a high temperature catalytic oxidation technique to analyse for DOC (e.g. Sugimura and Suzuki, 1988) initiated an international effort to resolve the long-standing lack of coordination and consensus in DOC analysis (e.g. UNESCO, 1992). Subsequent intercalibration exercises have led to the resolution of many analytical issues (Hedges et al., 1993; Sharp, 1993) and have shown that experienced DOC analysts and the use of suitable reference 
materials can produce comparable results regardless of the method used (Dafner and Wangersky, 2002a; Hansell and Carlson, 2001; Sharp et al., 2002).

(b) Characterization of the measured DOC has advanced significantly in recent decades (Lee and Henrichs, 1993; Aluwihare et al., 1997; Dafner and Wangersky, 2002b), with specific carbohydrates and aminoacids being readily identifiable as components of DOC (Hansell and Carlson, 2001). However, a significant proportion of DOC is often characterized as a whole class of compounds, e.g., humic acids and fulvic acids, or not characterized at all (Hansell and Carlson, 2001). Moreover, information about the labile or refractory nature of DOC and its role in ocean biogeochemistry is often deduced by its age using radiocarbon dating (e.g. Bauer et al., 1992; Druffel et al., 1992) or by its size (e.g. Dafner and Wangersky, 2002b). Therefore, reported DOC values should always be used by keeping the analytical methodologies and operational definitions which accompany them in perspective.

DOC is the second largest pool of carbon in the ocean after DIC (Pilson, 1998; Houghton, 2007), with oceanic DOC concentrations varying from just under $39 \mu \mathrm{mol} \mathrm{kg}^{-1}$ in the deep open ocean to over $195 \mu \mathrm{mol} \mathrm{kg}^{-1}$ at river-ocean margins (Sharp et al., 2002). The sheer size of the DOC pool, as well as the current interest in monitoring the fate of anthropogenic carbon emissions, yield a necessity for measuring DOC systematically, reliably and in high spatial and temporal frequency.

\subsection{Colored dissolved organic matter (CDOM)}

There is currently no sensor that can measure DOC. The greatest advance in this direction has been the development of sensors for CDOM, which is defined as the component of total dissolved organic matter (DOM) that absorbs light over a broad range of visible and UV wavelengths (Coble, 2007). Two optical properties of CDOM, absorbance and fluorescence, have been used to quantify CDOM. The absorption spectrum of CDOM in a sample can be used to calculate a spectral slope, which is empirically related to an absorption coefficient. Alternatively, the fluorescence of the fraction of CDOM that does fluoresce can be measured by excitation in the ultraviolet and measurement in the visible spectrum.

Both absorption coefficient and fluorescence of DOM have been correlated with each other and DOC concentrations (Bowers et al., 2004; Belzile et al., 2006; Coble, 2007; Röttlers and Doerffer, 2007), even though this is a casespecific endeavor, given that a direct correlation is not always the case (Hansell, 2002). However, the ability to measure CDOM remotely via satellite or aircraft, coupled with commonly positive correlations between the two parameters in coastal areas, where DOC concentrations and dynamics are some of the most intense in oceanic settings, has elevated CDOM to the status of a DOC proxy (see discussion in Coble, 2007).
There are numerous commercially available CDOM sensors (see Sect. 3.1 in Moore et al., 2008), and some have been successfully used on moored buoys to collect highfrequency CDOM fluorescence data (Belzile et al., 2006). A suite of suitable fluorometers has recently been evaluated by the Alliance of Coastal Technologies (http://www.act-us. info/evaluation_reports.php).

\subsection{Measurements of hydrocarbons}

Hydrocarbons are multi-carbon and multi-hydrogen saturated, unsaturated, and aromatic compounds, and include Polycyclic Aromatic Hydrocarbons (PAHs), which are products of the diagenetic alteration of organic material and usually the object of sensor development for petroleum detection (e.g., Zielinski et al. 2009).

Multispectral sensors employ the effect of hydrocarbon presence on the properties of absorption, fluorescence, and reflection to detect their presence and quantify their concentration (Zielinski et al., 2009). Of particular interest is the generation of excitation-emission matrices (EEM), by both sample excitation and spectrophotometric emission measurements of a single sample at multiple wavelengths (Moore et al., 2004). Another notable application of these sensors is the use of differences in fluorescence lifetime (defined as the average duration of time an organic molecule remains excited before relaxing and radiating a photon) to distinguish between different organic compounds or groups of compounds (Moore et al., 2008).

Special mention should be made of the demonstrated use of Surface-Enhanced Raman Scattering (SERS) in a sensor ("SERS optode") to measure PAHs (Schmidt et al., 2004). Raman Scattering is the technique by which a shift in the frequency of scattered laser light is related to the excitation of vibrational modes which are compound-specific. In SERS, molecules of the compounds under study are attached onto the surfaces of metallic nanostructures contained in suitable substrates to enhance the Raman signals. The reported limits of detection for this sensor ranged from $10^{-1}$ to $10^{2} \mathrm{nmol} \mathrm{kg}^{-1}$ (Schmidt et al., 2004).

\section{Summary}

Highly accurate and precise measurements of dissolved marine carbon are top priority to elucidate the causes for the variability of the marine carbon cycle on a global scale and to understand the anthropogenic impacts on the carbon cycle. The technological and operational challenges, however, to achieve such accurate and precise measurements, are numerous. In recent years, a great number of instruments and sensors have been developed, together with standards for e.g. DIC and TA (allowing globally consistent calibration) and standard operating procedures for dissolved inorganic carbon components. Yet there remains a great need for further developments to achieve the urgently needed increased spatial 
and temporal coverage of data; required improvements include e.g. smaller size, less power consumption, and longerterm stability. Additionally, instruments and sensors that are able to measure a combination of the marine carbon components are needed. In geographical regions where the access is difficult, such as the Southern Ocean, lower quality measurements might still be acceptable in order to obtain any data at all; yet in general, a range of instruments and sensors is needed for deployment on more ships, buoys, moorings, floats, robots, and gliders.

\section{Appendix A}

\section{Glossary of terms used in this paper.}

\begin{tabular}{|c|c|c|}
\hline \multirow{2}{*}{$\begin{array}{l}\text { Abbre- } \\
\text { viation }\end{array}$} & Term & Description \\
\hline & Accuracy & $\begin{array}{l}\text { The closeness of a measured } \\
\text { quantity to the its true value. }\end{array}$ \\
\hline \multirow[t]{2}{*}{ AT, ALK } & Alkalinity & See TA \\
\hline & Biological pump & $\begin{array}{l}\text { The "export" of biologically } \\
\text { bounded carbon from surface } \\
\text { waters to depth. }\end{array}$ \\
\hline CDOM & $\begin{array}{l}\text { Coloured Dissolved } \\
\text { Organic Carbon }\end{array}$ & $\begin{array}{l}\text { The optically measurable } \\
\text { fraction of the dissolved }\end{array}$ \\
\hline & & inorganic carbon. \\
\hline DIC & $\begin{array}{l}\text { Dissolved Inorganic } \\
\text { Carbon }\end{array}$ & $\begin{array}{l}\text { The sum of the concentrations } \\
\text { of dissolved } \mathrm{CO}_{2} \text {, bicarbonate } \\
\text { and carbonate; also depicted } \\
\text { as } C_{T} \text { or } \Sigma \mathrm{CO}_{2}, \text { or } \mathrm{TCO}_{2} \text {. }\end{array}$ \\
\hline DOC & $\begin{array}{l}\text { Dissolved Organic } \\
\text { Carbon }\end{array}$ & $\begin{array}{l}\text { Organic carbon remaining in } \\
\text { a sample after filtering } \\
\text { the sample, typically using } \\
\mathrm{a}<0.45 \mu \mathrm{m} \text { filter. }\end{array}$ \\
\hline
\end{tabular}

DOM Dissolved Organic Matter

$f \mathrm{CO}_{2} \quad$ Fugacity of $\mathrm{CO}_{2} \quad p \mathrm{CO}_{2}$ in air that is in equilibrium with seawater, taking into account the non-ideal behaviour of $\mathrm{CO}_{2}$ in seawater at atmospheric pressure.

FID Flame Ionisation Used to convert $\mathrm{CO}_{2}$ to $\mathrm{CH}_{4}$ Detector for gas chromatographic detection of $\mathrm{CO}_{2}$ in air.

GC Gas Chromatography Detection technique used to measure $x \mathrm{CO}_{2}$ in air.

Instrument An analytical system installed onboard ships, buoys, and moorings; it cannot be used in situ in subsurface deployments.

NDIR Non-Dispersive Infra- Detection technique used to red Absorption measure $x \mathrm{CO}_{2}$ in air.

NPOC Non-Purgeable Commonly referred to as TOC; Organic Carbon organic carbon remaining in a sample after purging the sample with gas.

PAH Polycyclic Armoatic Multi-carbon and -hydrogen Hydrocarbons saturated, unsaturated, and aromatic compounds.

\begin{tabular}{|c|c|c|}
\hline$p \mathrm{CO}_{2}$ & $\begin{array}{l}\text { partial pressure } \\
\text { of } \mathrm{CO}_{2}\end{array}$ & $\begin{array}{l}\text { The partial pressure of } \mathrm{CO}_{2} \text { in air } \\
\text { that is in equilibrium with seawater. } \\
p \mathrm{CO}_{2} \text { does not take into account } \\
\text { the non-ideal behaviour of } \mathrm{CO}_{2} \\
\text { in seawaterat atmospheric pressure. } \\
\text { Where an instrument/sensor is installed, } \\
\text { e.g. a ship, a buoy, a mooring, etc. }\end{array}$ \\
\hline \multirow[t]{2}{*}{ POC } & $\begin{array}{l}\text { Purgeable } \\
\text { (volatile) } \\
\text { Organic Carbon }\end{array}$ & $\begin{array}{l}\text { Organic carbon that has been sparged } \\
\text { or removed from a sample. }\end{array}$ \\
\hline & Precision & $\begin{array}{l}\text { A measure of the agreement between } \\
\text { repeated measurements of the same } \\
\text { sample; also referred to as reprodu- } \\
\text { cibility or repeatability. }\end{array}$ \\
\hline QA & \multicolumn{2}{|l|}{ Quality Assessment } \\
\hline \multirow[t]{2}{*}{ QC } & Quality Control & \\
\hline & Sensor & $\begin{array}{l}\text { An analytical system that can be } \\
\text { installed in situ on subsurface floats, } \\
\text { gliders, and robots. }\end{array}$ \\
\hline SOP & $\begin{array}{l}\text { Standard Opera- } \\
\text { ting Procedure }\end{array}$ & See Dickson et al. (2007). \\
\hline TA & Total Alkalinity & $\begin{array}{l}\text { The number of moles of } \mathrm{H}^{+} \text {equivalent } \\
\text { to the excess of proton acceptors in } 1 \mathrm{~kg} \\
\text { of sample. Also depicted as TAlk, or } A_{T} \text {. }\end{array}$ \\
\hline $\mathrm{TC}$ & Total Carbon & $\begin{array}{l}\text { All the carbon in the sample, including } \\
\text { both inorganic and organic carbon, and } \\
\text { both dissolved and particulate. }\end{array}$ \\
\hline TOC & $\begin{array}{l}\text { Total Organic } \\
\text { Carbon }\end{array}$ & $\begin{array}{l}\text { Material derived from decaying vege- } \\
\text { tation, bacterial growth, and metabolic } \\
\text { activities of living organisms or chemicals; } \\
\text { excluding total inorganic carbon. }\end{array}$ \\
\hline VOS & $\begin{array}{l}\text { Voluntary Obser- } \\
\text { ving Ships }\end{array}$ & $\begin{array}{l}\text { In most cases commercial ships on which } \\
\text { automated instrumentation is installed. } \\
\text { Also called Ships Of Opportunity (SOOP). }\end{array}$ \\
\hline$x \mathrm{CO}_{2}$ & $\begin{array}{l}\text { Mole fraction } \\
\text { of } \mathrm{CO}_{2}\end{array}$ & $\begin{array}{l}\text { The number of moles of } \mathrm{CO}_{2} \text { as } \\
\text { part of the total number of moles } \\
\text { within a parcel of air. }\end{array}$ \\
\hline
\end{tabular}

Acknowledgements. The authors acknowledge the large number of past and present marine carbon scientists and technologists, in their effort in improving existing sensors/instruments as well as developing new ones. The lead author is supported by the European Integrated Project CARBOOCEAN, grant number EVK2-CT-2000-00088

Edited by: G. Griffiths

\section{References}

Aluwihare, L. I., Repeta, D. J., and Chen, R. F.: A major biopolymeric component to dissolved organic carbon in surface sea water, Nature, 387, 166-169, 1997.

Bauer, J. E., Williams, P. M., and Druffel, E. R. M.: ${ }^{14} \mathrm{C}$ activity of dissolved organic carbon fractions in the north-central Pacific and Sargasso Sea, Nature, 357, 667-670, 1992.

Bellerby, R. G. J., Olsen, A., Johannessen, T., and Croot, P.: A high precision spectrophotometric method for on-line shipboard seawater $\mathrm{pH}$ measurements: the automated marine $\mathrm{pH}$ sensor (AMpS), Tallanta, 56, 61-69, 2002. 
Belzile, C., Roesler, C. S., Christensen, J. P., Shakhova, N., and Semiletov, I.: Fluorescence measured using the WETStar DOM fluorometer as a proxy for dissolved matter absorption, Estuar. Coast. Shelf Sci., 67, 441-449, 2006.

Bowers, D. G., Evans, D., Thomas, D. N., Ellis, K., and Williams, P. J. L.: Interpreting the colour of an estuary, Estuar. Coast. Shelf Sci., 59, 13-20, 2004.

Byrne, R. H. and Breland, J. A.: High precision multiwavelength $\mathrm{pH}$ determination in seawater using cresol red, Deep-Sea Res., 36, 803-810, 1989.

Charlou, J. L., Donval, J. P., Douville, E., Jean-Baptiste, P., Radford-Knoery, J., Fouquet, Y., Dapoigny, A., and Stievenard, M.: Compared geochemical signatures and the evolution of Menez Gwen $\left(37^{\circ} 50^{\prime} \mathrm{N}\right)$ and Lucky Strike $\left(37^{\circ} 17^{\prime} \mathrm{N}\right)$ hydrothermal fluids, south of the Azores Triple Junction on the Mid-Atlantic Ridge, Chem. Geol., 171, 49-75, 2000.

Coble, P. G.: Marine optical biogeochemistry: The chemistry of ocean color, Chem. Rev., 107, 402-418, 2007.

Cooper, D. J., Watson, A. J., and Ling, R. D.: Variation of $\mathrm{pCO}_{2}$ along a North Atlantic shipping route (UK to the Caribbean): A year of automated observations, Mar. Chem., 60, 147-164, 1998.

Dafner, E. V. and Wangersky, P. J.: A brief overview of modern directions in marine DOC studies - Part I. Methodological aspects, J. Environ. Monit., 4, 48-54, 2002a.

Dafner, E. V. and Wangersky, P. J.: A brief overview of modern directions in marine DOC sutdies Part II - Recent progress in marine DOC studies, J. Environ. Monit., 4, 55-69, 2002b.

deGrandpre, M. D., Baehr, M. M., and Hammar, T. R.: Development of an optical chemical sensor for oceanographic applications: The Submersible Autonomous Moored Instrument for Seawater $\mathrm{CO}_{2}$, in: Chemical Sensors in Oceanography, edited by: Varney, M., Gordon and Breach, Amsterdam, 123-141, 2000.

DelValls, T. A.: Underway pH measurements in upwelling conditions: The California Current, Ceinc. Mar., 25, 345-365, 1999.

Dickson, A. G.: An exact definition of total alkalinity and a procedure for the estimation of alkalinity and total inorganic carbon from titration data, Deep-Sea Res., 28, 609-623, 1981.

Dickson, A. G.: pH scales and proton-transfer reactions in saline media such as sea-water, Geochim. Cosmochim. Acta, 48, 2299_ 2308, 1984.

Dickson, A. G.: The measurement of seawater pH, Mar. Chem., 44, 131-142, 1993.

Dickson, A. G., Sabine, C. L., and Christian, J. R. (Eds.): Guide to best practices for ocean $\mathrm{CO}_{2}$ measurements, PICES Special Publication 3, 191 pp., 2007.

Druffel, E. R. M., Williams, P. M., Bauer, J. E., and Ertel, J. R.: Cycling of dissolved and particulate organic matter in the open ocean, J. Geophys. Res., 97, 15639-15659, 1992.

Feely, R. A., Wanninkhof, R., Milburn, H. B., Cosca, C. E., Stapp, M., and Murphy, P. P.: A new automated underway system for making high precision $\mathrm{pCO}_{2}$ measurements onboard research ships, Anal. Chim. Acta, 377, 185-191, 1998.

Friederich, G. E., Walz, P. M., Burczynski, M. G., and Chavez, F. P.: Inorganic carbon in the central California upwelling system during the 1997-1999 El Niño-La Niña event, Prog. Oceanogr., 54, 185-203, 2002.

Friis, K., Körtzinger, A., and Wallace, D. W. R.: Spectrophotometric $\mathrm{pH}$ measurement in the ocean: Requirements, design, and testing of an autonomous charge-coupled device detector system, Limnol. Oceanogr., 2, 126-136, 2004.

Grasshoff, K., Ehrhardt, M., and Kremling, K.: Methods of Seawater Analysis, 2nd ed., Verlag Chemie, Weinheim, 1983.

Hansell, D. A. and Carlson, C. A.: Marine dissolved organic matter and the carbon cycle, Oceanography, 14, 41-49, 2001.

Hansell, D. A.: DOC in the global ocean carbon cycle, in: Biogeochemistry of marine dissolved organic matter, edited by: Hansell, D. A. and Carlson, C. A., Academic Press, Amsterdam, The Netherlands, 685-715, 2002.

Hedges, J. I., Bergamaschi, B. A., and Benner, R.: Comparative analyses of DOC and DON in natural waters, Mar. Chem., 41, 121-134, 1993.

Houghton, R. A.: Balancing the global carbon budget, Annu. Rev. Earth Planet. Sci., 35, 313-347, 2007.

Körtzinger, A., Thomas, H., Schneider, B., Gronau, N., Mintrop, L., and Duinker, J. C.: At-sea intercomparison of two newly designed underway $\mathrm{pCO}_{2}$ systems - Encouraging results, Mar. Chem., 52, 133-145, 1996.

Körtzinger, A., Mintrop, L., and Duinker, J. C.: The international intercomparison exercise of underway $f \mathrm{CO}_{2}$ systems during the $R / V$ Meteor cruise 36-1 in the North Atlantic Ocean: comparison of $f \mathrm{CO}_{2}$ data, University of Kiel, Kiel, Germany, 1998.

Lee, C. and Henrichs, S. M.: How the nature of dissolved organicmatter might affect the analysis of dissolved organic-carbon, Mar. Chem., 41, 105-120, 1993.

Lefevre, N., Ciabrini, J. P., Michard, G., Brient, B., DuChaffaut, M., and Merlivat, L.: A new optical sensor for $p \mathrm{CO}_{2}$ measurements in seawater, Mar. Chem., 42, 189-198, 1993.

Lewis, E. and Wallace, D. W. R.: Program Development for $\mathrm{CO}_{2}$ System Calculations, Carbon Dioxide Information Analysis Center, Oak Ridge National Laboratory, US Department of Energy, Oak Ridge, Tennessee, ORNL/DCIAC-105, 26, 1998.

Lüger, H., Wallace, D. W. R., Körtzinger, A., and Nojiri, Y.: The $p \mathrm{CO}_{2}$ variability in the midlatitude North Atlantic Ocean during a full annual cycle, Global Biogeochem. Cy., 18, GB3023, doi:3010.1029/2003GB002200, 2004.

Moore, C., Da Cuhna, J., Rhoades, B., Twardowski, M. S., Zaneveld, J. R. V., and Dombroski, J.: A new in-situ measurement and analysis system for excitation-emission flourescence in natural waters, Ocean Optics XVII, Freemantle, Australia, 2004.

Moore, C., Barnard, A., Fietzek, P., Lewis, M. R., Sosik, H. M., White, S., and Zielinski, O.: Optical tools for ocean monitoring and research, Ocean Sci. Discuss., 5, 659-717, 2008, http://www.ocean-sci-discuss.net/5/659/2008/.

Murphy, P. P., Feely, R. A., and Wanninkhof, R.: On obtaining highprecision measurements of oceanic $\mathrm{pCO}_{2}$ using infrared analysers, Mar. Chem., 62, 103-115, 1998.

Nojiri, Y., Fujinuma, Y., Zeng, J., and Wong, C. S.: Monitoring of $p \mathrm{CO}_{2}$ with complete seasonal coverage utilizing a cargo ship M/S Skaugran between Japan and Canada/US, Second International Symposium of $\mathrm{CO}_{2}$ in the Oceans, CGER-Rep. CGER1037-'99, Tsukuba, Japan, 1999.

Pierrot, D., Neill, C., Sullivan, K., Castle, R., Wanninkhof, R., Luger, H., Johannessen, T., Olsen, A., Feely, R., and Cosca, C. E.: Recommendation for autonomous underway $p \mathrm{CO}_{2}$ measuring systems and data reduction routines, Deep-Sea Res. II, DeepSea Res. Pt. II, 56, 512-522, 2009.

Pilson, M. E. Q.: An Introduction to the Chemistry of the Sea, Pren- 
tice Hall, NJ, USA, 431 pp., 1998.

Robertson, J. E., Watson, A. J., Langdon, C., Ling, R. D., and Wood, J. W.: Diurnal variation in surface $p \mathrm{CO}_{2}$ and $\mathrm{O}_{2}$ at $60^{\circ} \mathrm{N}$, $20^{\circ} \mathrm{W}$ in the North Atlantic, Deep-Sea Res. II, 40, 409-422, 1993.

Röttlers, R. and Doerffer, R.: Measurements of optical absorption by chromophoric dissolved organic matter using a point-source integrating-cavity absorption meter, Limnol. Oceanogr., 5, 126135, 2007.

Schmidt, H., Bick, H. N., Pfannkuche, J., Amann, H., Kronfeld, H.D., and Kowalewska, G.: Detection of PAHs in seawater using surface-enhanced Raman scattering (SERS), Mar. Pollut. Bull., 49, 229-234, 2004.

Schuster, U. and Watson, A. J. W.: A variable and decreasing sink for atmospheric $\mathrm{CO}_{2}$ in the North Atlantic, J. Geophys. Res., 112, C11006, doi:10.1029/2006JC003941, 2007.

Sharp, J. H.: The dissolved organic carbon controversy: an update, Oceanography, 6, 45-50, 1993.

Sharp, J. H., Carlson, C. A., Peltzer, E. T., Castle-Ward, D. M., Savidge, K. B., and Rinker, K. R.: Final dissolved organic carbon broad community intercalibration and preliminary use of DOC reference materials, Mar. Chem., 77, 239-253, 2002.

Sugimura, Y. and Suzuki, Y.: A high-temperature catalyticoxidation method for the determination of non-volatile dissolved organic-carbon in seawater by direct injection of a liquid sample, Mar. Chem., 24, 105-131, 1988.
UNESCO: Methodologies for oceanic $\mathrm{CO}_{2}$ measurements. Final report of SCOR Working Group 75, Woods Hole, USA, UNESCO Technical papers in marine science, 65, 37, 1992.

Weiss, R. F.: Determinations of carbon dioxide and methane by daul catalyst flame ionization chromatogrphy and nitrous oxide by electron capture chromatography, J. Chromatogr. Sci., 19, 611616, 1981.

Weiss, R. F., Van Woy, F. A., and Salameh, P. K.: Surface water and atmospheric carbon dioxide and nitrous oxide observations by shipboard automated gas chromatography: results from expeditions between 1977 and 1990, Oak Ridge National Laboratory, Oak Ridge, Tennessee, USAORNL/CDIAC-59, NPD-044, 150, 1992.

Wolf-Gladrow, D. A., Zeebe, R. E., Klaas, C., Körtzinger, A., and Dickson, A. G.: Total alkalinity: The explicit conservative expression and its application to biogeochemical processes, Mar. Chem., 106, 287-300, 2007.

Zeebe, R. E. and Wolf-Gladrow, D. A.: $\mathrm{CO}_{2}$ in seawater: equilibrium, kinetics, isotopes, Elsevier Oceanography Book Series, Elsevier, Amsterdam, 346 pp., 2001.

Zielinski, O., Busch, J. A., Cembella, A. D., Daly, K. L., Engelbrektsson, J., Hannides, A. K., and Schmidt, H.: Detecting marine hazardous substances and organisms: sensors for pollutants, toxins, and pathogens, Ocean Sci. Discuss., 6, 953-1005, 2009, http://www.ocean-sci-discuss.net/6/953/2009/. 